\title{
Poly(vinyl chloride)-supported triazoles grafted onto calix[4]arene for chromium ions extraction
}

\author{
Ammar Said ${ }^{1), 3)}$ (ORCID ID:0000-0001-6484-8711), Mokhtar Dardouri ${ }^{1)}$ (0000-0003-3545-8815), \\ Fayçel Ammari'1), *) (0000-0003-3541-0854), Abid Ouerghui ${ }^{1), 2)}$ (0000-0001-9419-259X), \\ Nicholas P. Power ${ }^{3)}$ (0000-0002-4630-7580), Faouzi Meganem' ${ }^{1)}$ (0000-0002-0584-9754) \\ DOI: dx.doi.org/10.14314/polimery.2021.11.6
}

\begin{abstract}
A new suitable material was synthesized using click reaction between dialkynyl-p-tert-butylcalix[4]arene and poly(vinyl chloride) azide (PVC-N3). This novel dialkynyl-p-tert-butylcalix[4]arene with triazole groups grafted onto PVC polymer (PVC-0.75CX[4]) has an excellent extraction capability for chromium ions from aqueous solutions. It shows a unique ability to extract chromium (VI) ions from aqueous solutions. The soft cavity, the presence of $\pi$-triazole rings and hydrogen bonds play all essential roles in the removal of chromium species. $\mathrm{Cr}(\mathrm{VI})$ ion sorption capacity is $95.5 \%$ at $\mathrm{pH}=3$.
\end{abstract}

Keywords: calix[4]arene, poly(vinyl chloride), triazole, chromium(VI) extraction.

\section{Ekstrakcja jonów chromu z użyciem kaliks[4]arenu modyfikowanego triazolami szczepionego poli(chlorkiem winylu)}

\begin{abstract}
Streszczenie: $\mathrm{W}$ wyniku reakcji typu click między dialkynylo- $p$-tert-butylokaliks[4]arenem a azydkiem poli(chlorku winylu) (PVC-N ${ }_{3}$ ) otrzymano nowy związek - dialykynylo- $p$-tert-butylokaliks[4]aren z grupami triazolowymi szczepiony na poli(chlorku winylu) (PVC-0.75CX[4]). Wykazuje on wyjątkową zdolność do ekstrakcji jonów chromu(VI) z roztworów wodnych, dzięki sprężystej wnęce, obecności pierścieni $\pi$-triazolowych i wiązań wodorowych. Zdolność do sorpcji jonów $\mathrm{Cr}(\mathrm{VI})$ wynosi 95,5\% przy $\mathrm{pH}=3$.
\end{abstract}

Słowa kluczowe: kaliks[4]aren, poli(chlorek winylu), triazole, ekstrakcja jonów chromu(VI).

Calix[n]arenes are the third generation of supramolecular chemistry following crown ethers and cyclodextrines as first and second generations respectively [1]. However, calixarenes can be easily functionalized at one or both of its rims in order to exploit the potential of these macrocyclic compounds family and its derivatives for the removal of pollutants from environment [2-4]. As well known, the use of poly(vinyl chloride) (PVC) as an adsorbent material in the adsorption process in solutions is very scanty [5]. In addition, the chemical modification of PVC generates an opportunity to produce a novel material with interesting features. PVC containing chelating moieties and triazoles had the capacity to separate heavy

\footnotetext{
1) University of Carthage, Faculty of Sciences of Bizerte, Laboratory of Organic Chemistry and Applications, Bizerte 7021, Tunisia.

2) Laboratory of Functional Physiology and Valuation of Bioresources (UR17ES27), Higher Institute of Biotechnology of Béja, B.P. 382-9000 Beja, University of Jendouba, Tunisia.

3) The Open University, Faculty of Science, School of Life Health \& Chemical Sciences, Walton Hall, Milton Keynes MK7 6AA, UK.

*) Author for correspondence: ammari1971@gmail.com
}

metals from aqueous solutions [6]. Recently, chromate and dichromate anions have been attracted a lot of attention, because of their bioaccumulation and non-biodegradability in the environment as well as high toxicity and persistent character in ground water and soil. As a consequence, several studies have invented some technologies for the removal of toxic metal ions from waste water before releasing into our environment. Moreover, they have applications in host-guest chemistry [7] as sensors [8], calixarene derivatives as biosensors [9], catalysts [10], solid-liquid extractants that can provide a selective separation and recovery of pollutants from the effluent mixtures. In addition, the studies on using calixarenes based covalent polymers are rare, however the covalent polymers functionalized with calixarenes have the capacity for removal of metal ions and several toxins. Therefore, many studies developed some new polymeric adsorbents for removal of heavy metals from aqueous media, several of them have been reported in literature. For example, Chen $e t$ al. synthesized a novel biopolymeric adsorbent based on the starch grafted $p$-tert-butylcalix[n]arenes (SGC4, SGC6, SGC8) as a potential extractant used for dyes and organic wastewater [11]. Besides, Kitano et al. studied the complexation of Bisphenol A with calix[6] 
arene-polymer conjugates [12]. Then, Trivedi et al. prepared a novel material calix[6]hydroxyamide-based polymer for complexing uranium, thorium, and cerium [13]. Also, Tabakci et al. studied the adsorption properties of calix[4]arene-chitosan polymers towards particular heavy metals cations $\left(\mathrm{Co}^{2+}, \mathrm{Hg}^{2+}, \mathrm{Cu}^{2+}, \mathrm{Cd}^{2+}, \mathrm{Pb}^{2+}, \mathrm{Ni}^{2+}\right.$ and $\left.\mathrm{Cr}_{2} \mathrm{O}_{7}{ }^{2-}\right)$, exceeding chitosan [14]. Moreover, Prabawati et al. synthesized three novel polymers [poly(monoallyloxy calix[6]arene), monoallyloxy penta-ester calix[6]arene and poly(monoallyloxy penta-acid calix[6]arene)] as heavy metal cations [Cd(II), $\mathrm{Cu}(\mathrm{II})$, and $\mathrm{Cr}(\mathrm{III})]$ extractants. Then the presence of hydroxyl group in polymer structure caused an increased area for better separation of heavy metals [15]. Chromium as an ecotoxic pollutant is very dangerous because of its accumulative and persistent character in the environment so it needs to be removed from water. Thereby, Khan et al. synthesized an effective calix[4]arene functionalized XAD-4 resin used in the sorption of $\mathrm{Cr}(\mathrm{VI})$ from water [16].

The aim of our studies is to present the preparation, characterization and removal properties of polymeric material towards $\mathrm{Cr}(\mathrm{VI})$ ions from aqueous solutions. The synthesized polymeric material was synthesized in two steps. In the first step calix[4]arene was transformed into dipropargylcalix[4]arene. The second step associated a coupling reaction between the derivative dipropargylcalix[4]arene and the azide functionalized poly(vinyl chloride) (PVC- $\mathrm{N}_{3}$ ) via click chemistry based on the CuAAC or copper(I)-catalyzed Huisgen's reaction. Synthesized materials were characterized using FT-IR, elemental analysis (EA), GPC, and TGA/DSC thermal analysis.

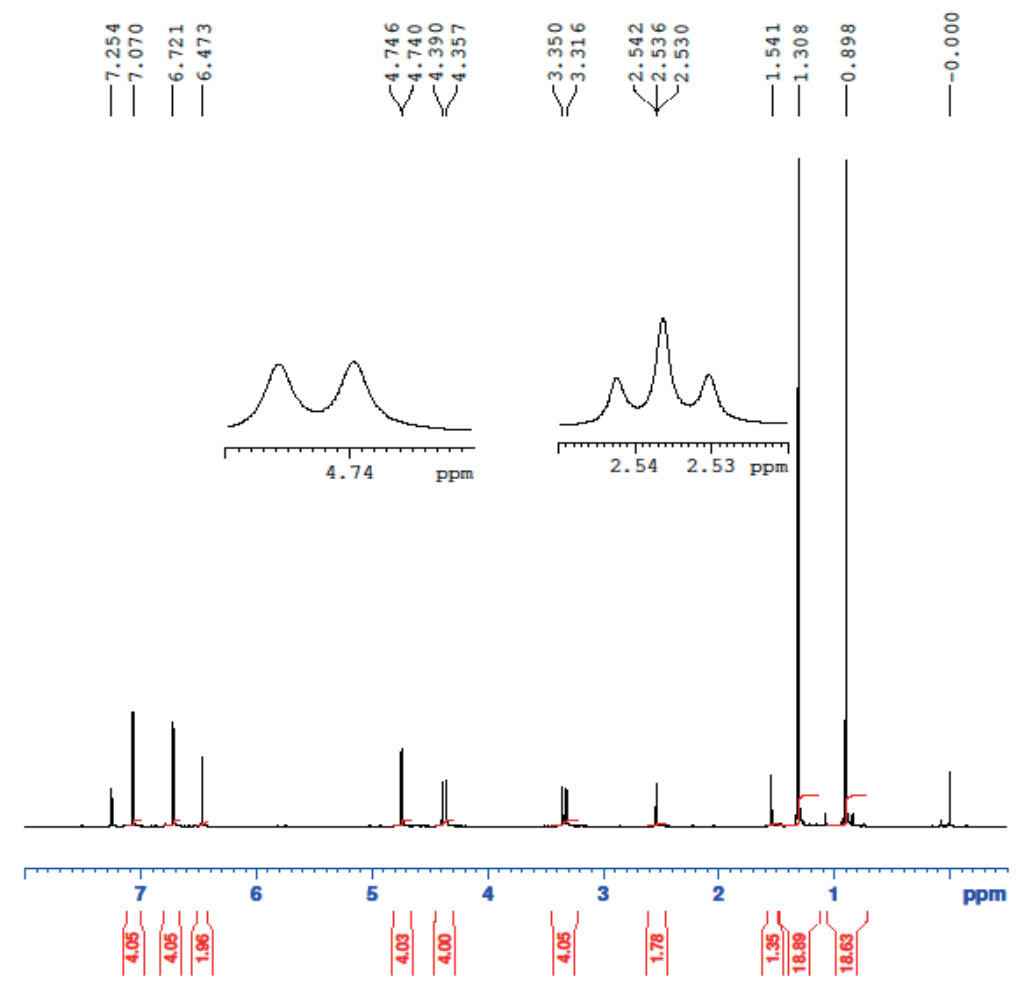

Fig. 1. ${ }^{1} \mathrm{H}$-NMR spectrum of cone-5,11,17,23-tetra-tert-butyl-25,27-dihydroxy-26,28-dipropargylcalix[4]arene

\section{EXPRIMENTAL PART}

\section{Materials}

Poly(vinyl chloride) (PVC) powder $\left(M_{w}=43000\right)$ was purchased from Fluka, $\mathrm{NaN}_{3}$ powder $(\geq 99.5 \%)$, tetrahydrofuran (THF, $\geq 99.0 \%$ ), formaldehyde $(\mathrm{HCHO}, 37 \mathrm{wt} \%$ in $\left.\mathrm{H}_{2} \mathrm{O}\right)$, p-tert-butylphenol (99\%), ethyl acetate (EtOAc, $99.8 \%)$, acetic acid and acetone $(\geq 99.9 \%)$, toluene $(99.8 \%)$, potassium carbonate $\left(\mathrm{K}_{2} \mathrm{CO}_{3^{\prime}} \geq 99.0 \%\right)$, acetonitrile $(99.8 \%)$, hexane $(\geq 99 \%)$, dichloromethane $(\geq 99.5 \%)$, methanol ( $\geq 99.9 \%), N, N$-diisopropylethylamine $(99.5 \%)$, copper(I) iodide ( $\geq 99.5 \%$ ) were bought from Sigma Aldrich and used without further purification. Deionized water was used in some synthesis.

\section{Methods}

\section{Synthesis of PVC-N}

$5 \mathrm{~g}$ of poly(vinyl chloride) $(16 \mathrm{mmol} \mathrm{Cl})$ was dissolved in $200 \mathrm{ml}$ of dimethylformamide (DMF). Then, $8 \mathrm{~g}$ of $\mathrm{NaN}_{3}(123 \mathrm{mmol}, 7.7 \mathrm{eq})$ was added. After cooling down at room temperature, the product precipitated in a mixture of water and methanol $(\mathrm{v} / \mathrm{v})$, and was filtered on sintered glass and dried in vacuum oven. The weight of obtained polymer was $4.85 \mathrm{~g}$ and its form was a white powder. It had low solubility in THF and was practically insoluble in the other organic solvents [6]. The identification of its chemical structure was conducted by FT-IR and elemental analysis, for the IR spectra the characteristic peaks were: $v_{\mathrm{N} 3}=2100, v_{\mathrm{OH}}=3316, v_{\mathrm{N}=\mathrm{N}}=1655 \mathrm{~cm}^{-1}$. The elemental 
analysis allowed us to determine the number of moles of chlorine substituted by the azide group $\left(\mathrm{N}_{3}\right)$ in the polymer mass, the result was $27.35 \mathrm{mmol} \mathrm{N} / \mathrm{g}$ or $9.11 \mathrm{mmol}$ $\mathrm{N}_{3} / \mathrm{g}$ fixed on the polymer mass. The percentage of the elements was: $\% \mathrm{C}=39.15, \% \mathrm{H}=4.39, \% \mathrm{~N}=38.31$.

\section{Synthesis of $p$-tert-butylcalix[4]arene}

$p$-tert-butylcalix[4]arene is a macrocyclic compound formed from $p$-tert-butylphenol and formaldehyde condensations. The preparation of $p$-tert-butylcalix[4]arene was a several-step sequence which followed a well developed literature procedure as was reported by Gutsche and Iqbal [17]. The ${ }^{1} \mathrm{H}$ NMR spectra $\left(400 \mathrm{MHz} \mathrm{CDCl}_{3^{\prime}}\right.$ $\mathrm{Me}_{4} \mathrm{Si}$ ) showed 4.23 and $4.27 \mathrm{ppm}\left(\mathrm{d}, 4 \mathrm{H}, \mathrm{ArCH}_{2} \mathrm{Ar}\right)$, 3.47 and $3.50 \mathrm{ppm}\left(\mathrm{d}, 4 \mathrm{H}, \mathrm{ArCH}_{2} \mathrm{Ar}\right), 10.33 \mathrm{ppm}(\mathrm{S}$, $4 \mathrm{H}, \mathrm{ArOH}), 7.04 \mathrm{ppm}(\mathrm{S}, 8 \mathrm{H}, \mathrm{ArH}), 1.21 \mathrm{ppm}[\mathrm{S}, 18 \mathrm{H}$, $\left.\mathrm{C}\left(\mathrm{CH}_{3}\right)_{3}\right] .{ }^{13} \mathrm{C} \mathrm{NMR}$ spectra $\left(400 \mathrm{MHz}, \mathrm{CDCl}_{3}, \mathrm{Me}_{4} \mathrm{Si}\right)$ showed: 31.41 ppm $\left[\mathrm{C}\left(\mathrm{CH}_{3}\right)_{3}\right], 32.62$ and $34.01 \mathrm{ppm}$ $\left(\mathrm{CH}_{2} \mathrm{Ar}\right), 146.68$ and $144.38 \mathrm{ppm}\left(\mathrm{CMe}_{3} \mathrm{Ar}\right)$, and 129.05, 128.24, 127.70, 125.94 and 125.31 ppm (Ar). Yield was 49\%, for $\mathrm{C}_{44} \mathrm{H}_{56} \mathrm{O}_{4}, \mathrm{M}^{+} \mathrm{H}_{2} \mathrm{O}=666.21 \mathrm{~m} / \mathrm{z}$. FT-IR (ATR) analysis showed phenolic-OH stretching at around $3163 \mathrm{~cm}^{-1}$; 2953 and $2867 \mathrm{~cm}^{-1}$ were assigned to $\mathrm{C}-\mathrm{H}\left(\mathrm{sp}^{3}\right)$ and $\mathrm{C}-\mathrm{H}\left(\mathrm{sp}^{2}\right)$ stretching respectively. 1594 and $1466 \mathrm{~cm}^{-1}$ were assigned for $\mathrm{C}=\mathrm{C}$ stretching.

\section{Synthesis of cone-5,11,17,23-tetra-tert-butyl-25,27-} dihydroxy-26,28-dipropargylcalix[4]arene

$8 \mathrm{~g}$ (12.32 mmol) of $p$-tert-butylcalix[4]arene and $4.12 \mathrm{~g}$ (29.28 mmol) of potassium carbonate were suspended in acetonitrile $(150 \mathrm{ml})$ and refluxed under inert atmo-

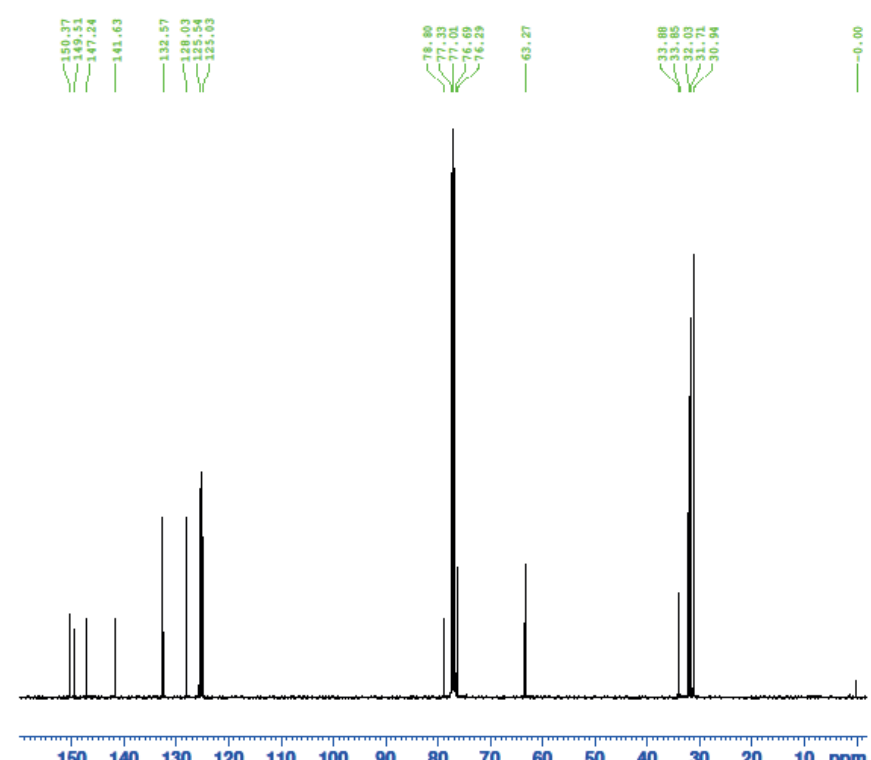

Fig. 2. ${ }^{13} \mathrm{C}-\mathrm{NMR}$ spectrum of cone-5,11,17,23-tetra-tert-butyl-25,27-dihydroxy-26,28-dipropargylcalix[4]arene sphere for about one hour until the most of reagents were dissolved. Afterwards, to this stirred mixture 5.04 $\mathrm{g}$ (42.38 mmol, $3.77 \mathrm{ml}$ ) of propargyl bromide $(80 \mathrm{wt} \%$ solution in toluene) in acetonitrile $(30 \mathrm{ml})$ was added dropwise for one hour and the reaction mixture was refluxed for 36 hours [18]. The yield of the synthesis was $80 \%$, ESI-MS result was $M_{W}=725.02$, calculated for $\mathrm{C}_{50} \mathrm{H}_{60} \mathrm{O}_{4^{\prime}} \mathrm{M}^{+} \mathrm{H}_{2} \mathrm{O}=742.45 \mathrm{~m} / \mathrm{z} .{ }^{1} \mathrm{H}$ NMR $\left(\mathrm{CDCl}_{3}\right)$, Fig. 1, showed: $\delta=7.25$ ppm (S, 2H, ArOH), $7.07 \mathrm{ppm}(\mathrm{S}, 4 \mathrm{H}$, $\mathrm{ArH}), 6.72 \mathrm{ppm}(\mathrm{S}, 4 \mathrm{H}, \mathrm{ArH}), 6.47 \mathrm{ppm}(\mathrm{S}, 2 \mathrm{H}, \mathrm{CCH})$, $4.74 \mathrm{ppm}\left(\mathrm{d}, 4 \mathrm{H}, \mathrm{OCH}_{2} \mathrm{C}\right), 4.39 \mathrm{ppm}\left(\mathrm{d}, 4 \mathrm{H}, \mathrm{ArCH}_{2} \mathrm{Ar}\right)$,

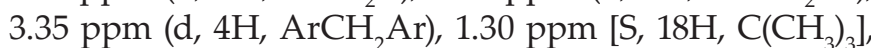
0.89 ppm $\left[\mathrm{S}, 18 \mathrm{H}, \mathrm{C}\left(\mathrm{CH}_{3}\right)_{3}\right] .{ }^{13} \mathrm{C} \mathrm{NMR}$ spectra $\left(\mathrm{CDCl}_{3}\right)$, Fig. 2, showed: $\delta=150.37,147.24,141.63,132.57$ ppm (Ar), 128.04 ppm $\left(\mathrm{CMe}_{3}\right), 125.54-125.03$ ppm (ArH), $78.80 \mathrm{ppm}$ (-C $\equiv)$, 63.27 ppm (ArCH $\left.{ }_{2} \mathrm{Ar}\right), 33.85-33.88$ ppm $\left(\mathrm{OCH}_{2} \mathrm{C}\right)$, 30.95, 31.72 and 32.03 ppm $\left(\mathrm{CMe}_{3}\right)$.

The DEPT-135 spectrum (Fig. 3) is in similarity with ${ }^{13} \mathrm{C}$ and ${ }^{1} \mathrm{H}$ which proved the obtained molecular structure.

\section{Synthesis of azide-PVC/dialkylated-p-tert- -butylcalix[4]arene material}

$2 \mathrm{~g}$ of PVC-N $\mathrm{N}_{3}\left(18.22 \mathrm{mmol}\right.$ of $\left.\mathrm{N}_{3}\right), 1.5 \mathrm{~g}$ (2.068 mmol) of dipropargylcalix[4]arene, $1.26 \mathrm{~g}(8.79 \mathrm{mmol})$ of cuprous bromide and $2.76 \mathrm{~g}(17.7 \mathrm{mmol})$ of 2,2'-dipyridine in $40 \mathrm{ml}$ of DMF were mixed together and the mixture was stirred and kept at a temperature of $30-40^{\circ} \mathrm{C}$ for 24 hours. After cooling down, the product was precipitated in water and methanol (v/v). Thereafter, it was filtered in order to remove copper salts. After that it was dried overnight in an oven vacuum at $50^{\circ} \mathrm{C}$ to afford PVC-0.75CX[4] as purified and final material (Scheme 1).

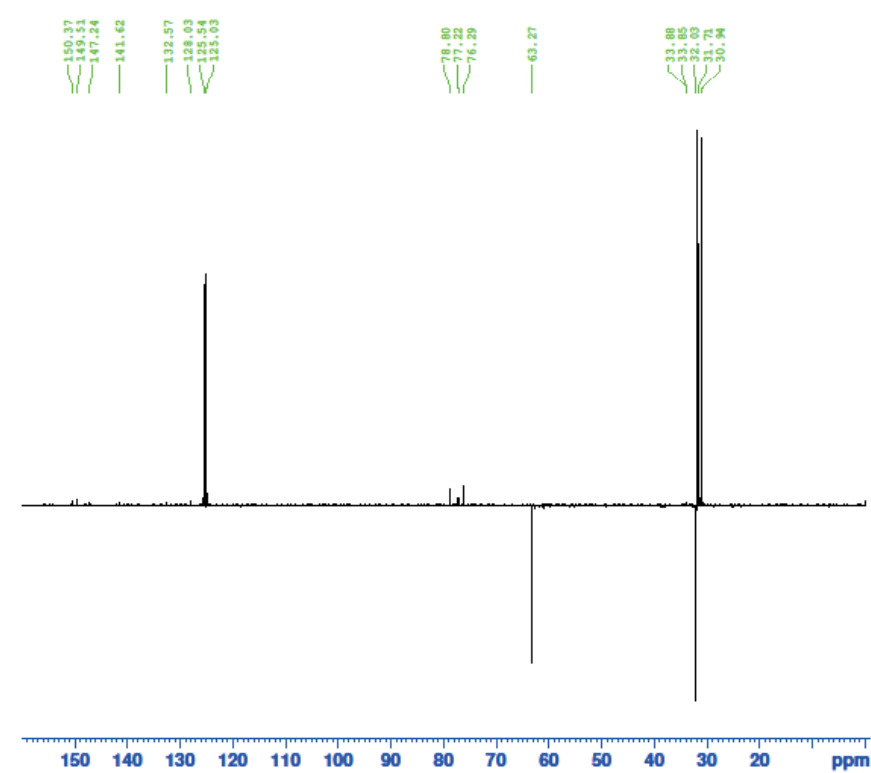

Fig. 3. DEPT-135 spectrum of cone-5,11,17,23-tetra-tert-butyl-25,27-dihydroxy-26,28-dipropargylcalix[4]arene 


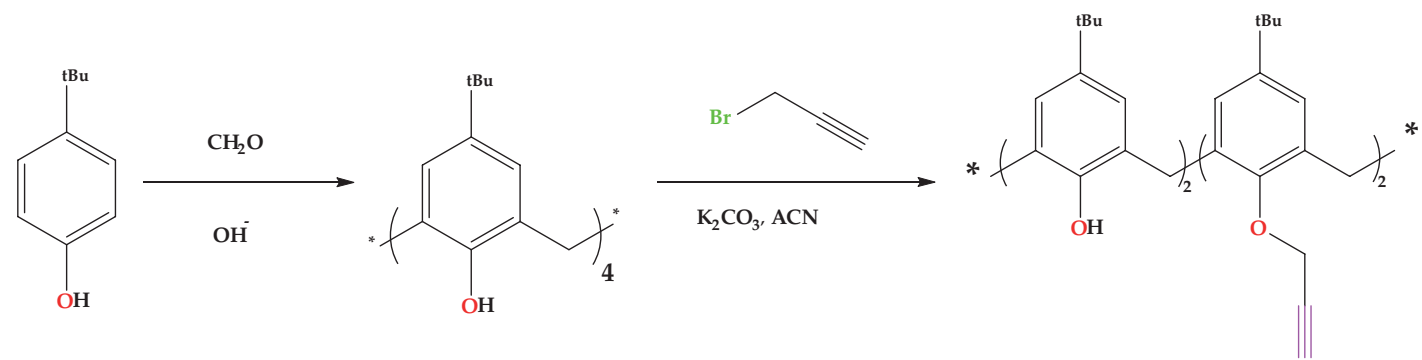

Step 1

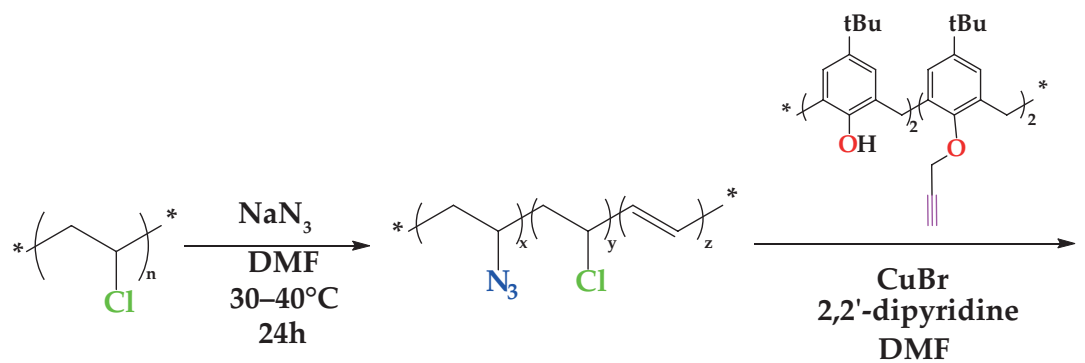

Step 2

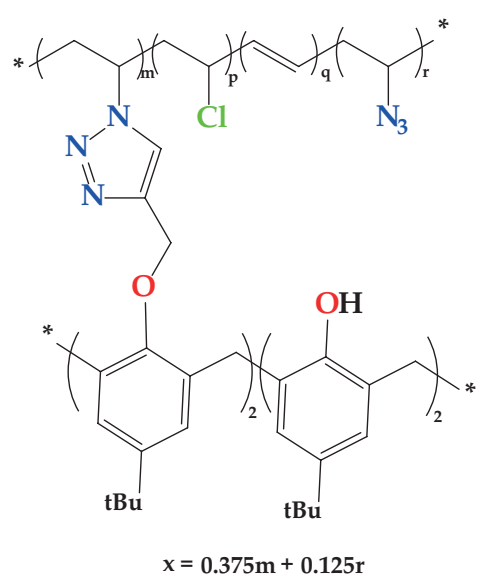

Scheme 1. Mechanism of the formation of the PVC/calixarene derivatives

\section{Methods of testing}

Fourier transform infrared spectrometry (FT-IR) was recorded on a Nicolet iS10 FT-IR for different polymers spectra in the range of $500-4000^{\circ} \mathrm{C}$.

The ${ }^{1} \mathrm{H},{ }^{13} \mathrm{C}$ and DEPT-135 NMR data of $p$-tert-butylcalix[4]arene and dipropargylcalix[4]arene were processed using $500 \mathrm{MHz}$ NMR spectrometer Brukerand with $\mathrm{CDCl}_{3}$ as a solvent and TMS as an internal standard.

CHN elemental analysis was performed using an Exeter CE-440 Elemental Analyzer.

Gel Permeation Chromatography (GPC) measurement (Agilent GPC/SEC Software Version 1.2.3182.29519) at RT (flow rate: $1 \mathrm{ml} / \mathrm{min}$, column: mixed PL gel $300 \times 718 \mathrm{~mm}$, $25 \mu \mathrm{m})$ with HPLC-grade THF as solvent was used for performing average molar weight and dispersity of PVC and PVC functionalized calixarene.

TGA/DSC simultaneous thermogravimetric analysis with differential scanning calorimetry was carried out using a TA instruments SDT Q600 unit. In a standard analysis, a sample of $6 \mathrm{mg}$ was heated up in a temperature range of $20-800^{\circ} \mathrm{C}$ at a heating rate of $5^{\circ} \mathrm{C} / \mathrm{min}$ under nitrogen.

Inductively Coupled Plasma Optical Emission Spectroscopy (ICP-OES) (Agilent 5110 ICP-OES) was used for the quantification of ion concentration in aqueous solutions. The results were reported in parts per million (ppm).

\section{RESULTS AND DISCUSSION}

\section{FT-IR analysis}

The IR spectra of PVC- $\mathrm{N}_{3}$ and its derivative supported 1,2,3-triazole (PVC-0.75CX[4]) are shown in Fig. 4. A progressive decrease in the peak intensity of azide functional group at $2111 \mathrm{~cm}^{-1}$ with the loading amount of calix[4] arene onto the PVC chain [6] can be observed. The FT-IR

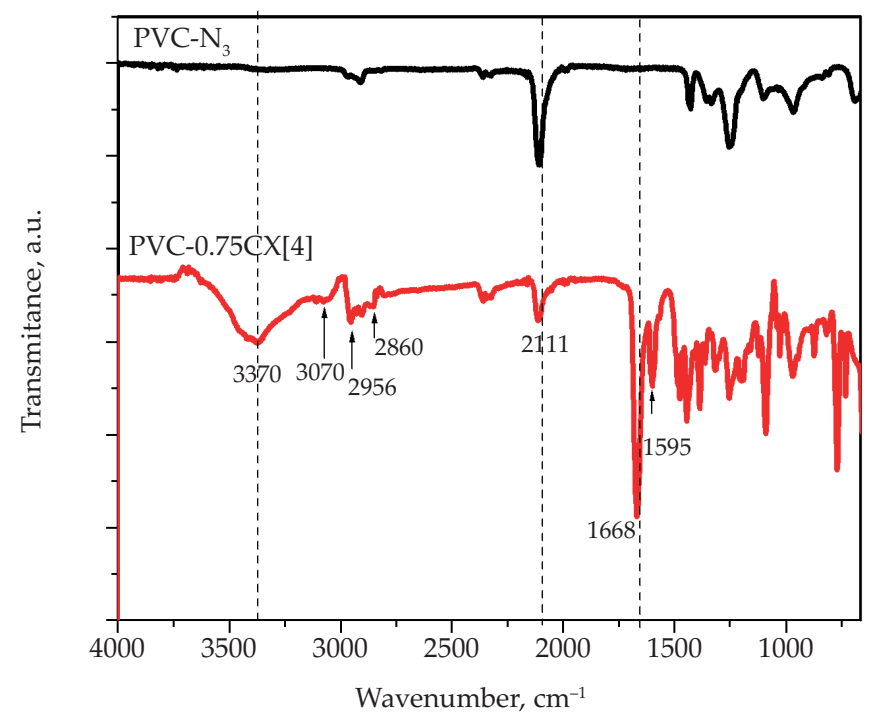

Fig. 4. FT-IR spectra of PVC-N $\mathrm{N}_{3}$ and PVC-0.75CX[4] 
T a b l e 1. The content of $\mathrm{C}, \mathrm{H}, \mathrm{N}$ in PVC- $\mathrm{N}_{3}$ and PVC-0.75CX[4]

\begin{tabular}{c|c|c|c|c}
\hline Samples & $\mathrm{C}, \%$ & $\mathrm{H}, \%$ & $\mathrm{~N}, \%$ & $\mathrm{~N}, \mathrm{mmol} / \mathrm{g}$ \\
\hline PVC-N $_{3}$ & 39.15 & 4.39 & 38.31 & 27.35 \\
PVC-0.75CX[4] & 53.53 & 5.86 & 9.20 & 6.57 \\
\hline
\end{tabular}

T a b l e 2. Relative molecular weight and distribution of PVC and its derivatives

\begin{tabular}{c|c|c|c}
\hline PVC derivatives & $\begin{array}{c}\text { Average relative molecular } \\
\text { weight } M_{n^{\prime}} \mathrm{g} / \mathrm{mol}\end{array}$ & $\begin{array}{c}\text { Average molecular weight } \\
M_{w^{\prime}} \mathrm{g} / \mathrm{mol}\end{array}$ & $\begin{array}{c}\text { Dispersity } \\
M_{n} / M_{w^{\prime}} \mathrm{g} / \mathrm{mol}\end{array}$ \\
\hline Pristine PVC & 11172 & 28787 & 2.5 \\
PVC-N & 17707 & 34668 & 2 \\
PVC-0.75CX[4] & 32989 & 46449 & 1.4 \\
\hline
\end{tabular}

spectrum confirmed that the conversion of azide groups to triazole rings is a partial process. The appearance of a new strong band at $1668 \mathrm{~cm}^{-1}$ indicates the $\mathrm{C}=\mathrm{C}$ ring stretch, and a very small $\mathrm{N}=\mathrm{N}$ band is visible at $1595 \mathrm{~cm}^{-1}$. The IR spectra showed also a broad absorbance band at $3370 \mathrm{~cm}^{-1}$ which was assigned to the $\mathrm{OH}$ stretching of phenols, the absorbance bands at $2956-2860 \mathrm{~cm}^{-1}$ due to the $\mathrm{CH}_{2}$ stretching modes, and the band at $3070 \mathrm{~cm}^{-1}$ for unreacted $\equiv \mathrm{CH}$ function. These IR results suggested that the conversion to the triazole groups was still partial. Whereas the FT-IR spectra materials presented a similarity due to the same triazole calix[4]arenes linked on PVC chain.

\section{Elemental analysis (EA)}

Table 1 summarizes the percentages of carbon, hydrogen and nitrogen of different synthesized materials. The results of the elemental analysis showed that the nitrogen content in the two resins PVC-N ${ }_{3}$ and PVC-0.75CX[4] was, respectively, 38.31 and $9.2 \%$. Furthermore, their molar nitrogen content calculated from the elemental analysis was 27.35 and $6.57 \mathrm{mmol} / \mathrm{g}$ respectively. The results suggested that the structure of the resin, particularly the

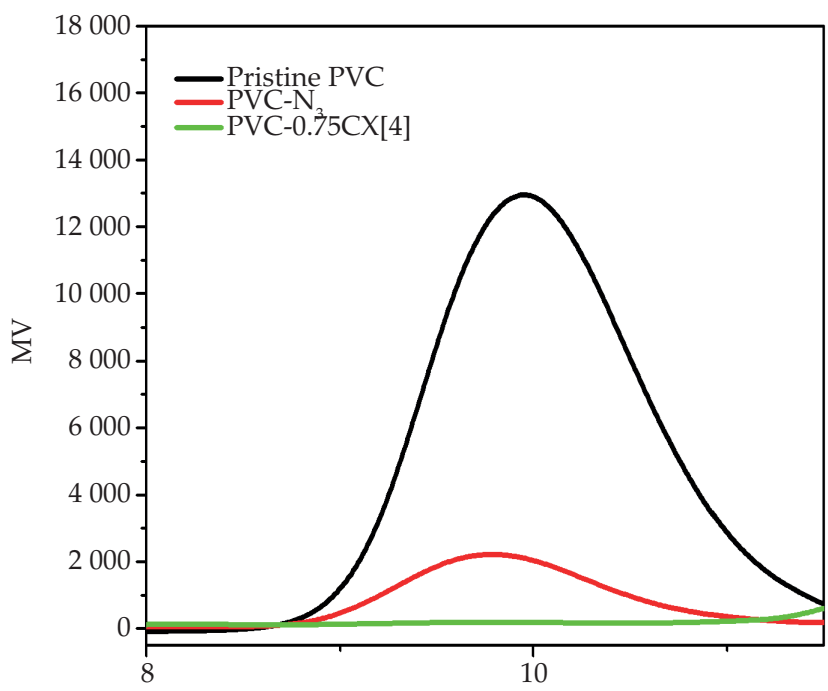

Fig. 5. GPC spectra of pristine PVC and PVC functionalized calixarene amount ratio of the calixarenes, influenced the nitrogen content.

GPC spectra of PVC and its derivatives, shown in Fig. 5 and Table 2, outlined data of relative molecular weight and distribution of PVC derivatives. However, a single broad peak in GPC chromatogram of PVC materials with a clear shift to a higher molecular weight region indicated the monodispersity of these polymeric materials. Moreover, the decrease in the peak area with the increase of loaded calixarene unities occurred due to the filtration of highly branched polymers. The data collected in Table 2 indicated that the increase of calixarene units covalently bonded to PVC- $\mathrm{N}_{3}$ structure using click chemistry reaction increased the $M_{n}$ of PVC derivatives (from 11172 to $32989 \mathrm{~g} / \mathrm{mol}$ ) and $M_{w}$ (from 28787 to $46449 \mathrm{~g} / \mathrm{mol}$ ).

\section{TGA/DSC thermal analysis}

The TGA/DSC thermograms of pristine PVC and PVC functionalized calixarene recorded for $6 \mathrm{mg}$ sample with a heating rate of $5^{\circ} \mathrm{C} / \mathrm{min}$ under nitrogen in the temperature range of 20 to $800^{\circ} \mathrm{C}$ are shown in Fig. 6. The DSC curve showed broad endothermic peak in the range from 20 to $180^{\circ} \mathrm{C}$ corresponding to a loss of moisture of a sample, and three endothermic peaks, respectively at $280^{\circ} \mathrm{C}, 325^{\circ} \mathrm{C}, 454^{\circ} \mathrm{C}$, indicating the polymer decomposition which took place in stages. The endothermic peak at $280^{\circ} \mathrm{C}$, accompanied by a significant loss weight of $23.86 \%$ in the temperature range $220-350^{\circ} \mathrm{C}$, occurred probably due to the dehydrochlorination of poly(vinyl chlorine) [19]. Then the small sharp endothermic peak at $325^{\circ} \mathrm{C}$, followed with a significant loss weight of $56.7 \%$ in the range temperature of $310-360^{\circ} \mathrm{C}$, possibly was due to the water molecule release. The other endothermic peak at $454^{\circ} \mathrm{C}$, accompanied with an important loss weight of $\sim 77 \%$ in the range temperature of $400-535^{\circ} \mathrm{C}$ [20], was attributed to the PVC major degradation. The TGA/DSC curves for PVC functionalized calixarene were similar. However, a broad endothermic peak due to the moisture desorption in the temperature range of $20-100^{\circ} \mathrm{C}$ and three sharp important endothermic peaks at 130 and $216^{\circ} \mathrm{C}$ could be observed. The latter endothermic peaks are attributed to the major polymers degradation which consequence was a gradual decrease of PVC derivates weight loss in 
a)

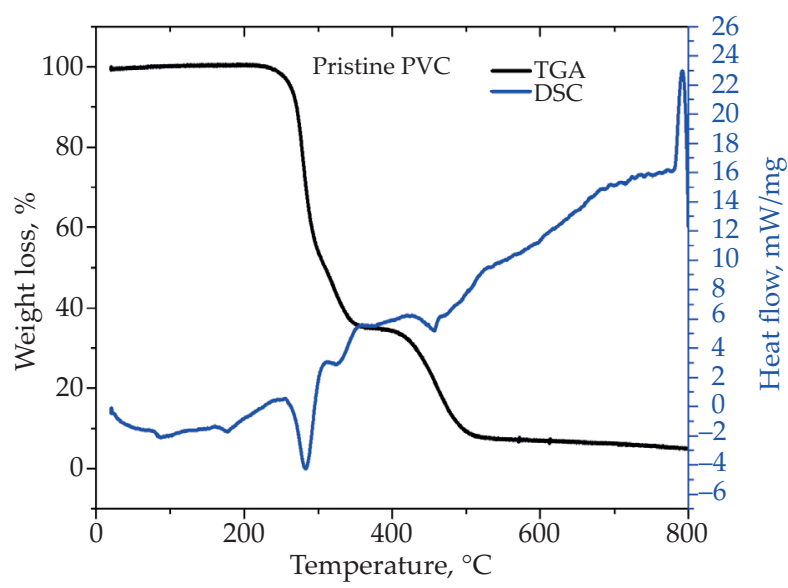

Fig. 6. TGA/DSC curves of: a) pristine PVC and b) PVC-0.75CX[4]

temperature range $\sim 280-454^{\circ} \mathrm{C}$, possibly due to the PVC peak displacement.

\section{Cr(VI) extraction experiments}

In order to explore the effect of $\mathrm{pH}$ on the sorption of chromate ions from aqueous solutions onto PVC-0.75CX[4] at $25^{\circ} \mathrm{C}$ in the $\mathrm{pH}$ range of $1-10, \mathrm{KOH}$ and $\mathrm{HCl}(1 \mathrm{~mol} / \mathrm{l})$ were added to the aqueous solutions to adjust the $\mathrm{pH}$ values to the desired one from given $\mathrm{pH}$ range. All batch adsorption experiments were carried out to determine concentration by exploiting the same adsorption process as that reported in [21]. The examined $10^{-4} \mathrm{M}$ solutions were prepared with potassium dichromate $\left(\mathrm{K}_{2} \mathrm{Cr}_{2} \mathrm{O}_{7}\right)$. $25 \mathrm{mg}$ of PVC-0.75CX[4] and $10 \mathrm{ml}$ of dichromate solution at given $\mathrm{pH}$ were mixed in batches for solid-liquid extraction. Then the prepared mixtures were stirred at $1700 \mathrm{rpm}$ for 1 hour at room temperature and filtered using $0.2 \mu \mathrm{m}$ syringe filters to separate the polymers. The chromate concentration was measured before and after sorption process by ICP-OES. Dichromate sorption percentages (\% Sorption) were calculated using the following equation (1):

$$
\text { \% Sorption }=\frac{\left(C_{i}-C_{e}\right)}{C_{e}} \cdot 100
$$

where: $C_{i}$ - initial concentration of chromate(VI) in aqueous solution,

$C_{e}$ - equilibrium concentration of chromate(VI) in aqueous solution.

\section{$\mathrm{pH}$ effect on the sorption of $\mathrm{Cr}(\mathrm{VI})$}

The effectiveness of the synthesized material as an extractant of $\mathrm{Cr}(\mathrm{VI})$ from aqueous solutions depended on $\mathrm{pH}$ of the sorption medium. The mechanism of the sorption process of $\mathrm{Cr}(\mathrm{VI})$ onto the adsorbent polymer was the protonation/deprotonation of the different nitrogen atoms in triazole ring (Fig. 8). A static method at a $\mathrm{pH}$ range b)

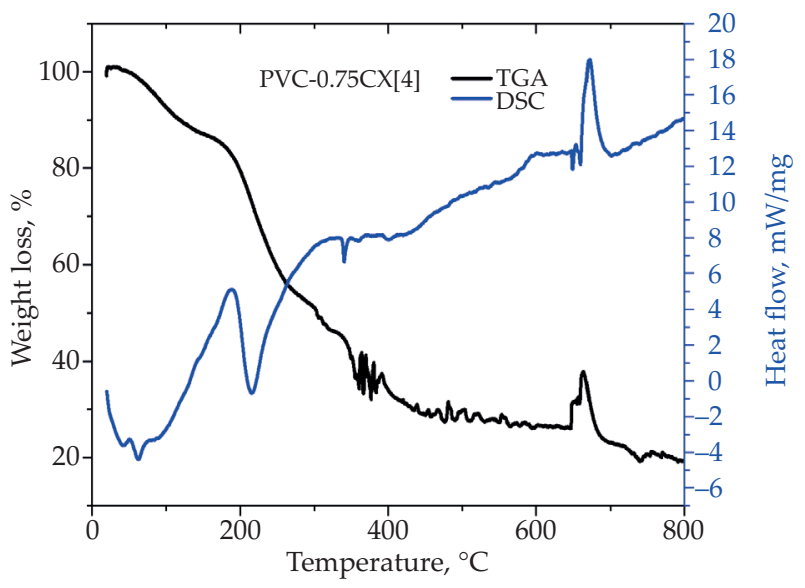

1-10 was performed to examine the sorption process of chromate and dichromate ions using PVC-0.75CX[4] polymer with an initial concentration of solutions $10^{-4} \mathrm{~mol} / 1$ and after 1 hour of stirring. Once the equilibrium has been reached, the sorption results (Fig. 7) showed a high sorption percentage of about $95.5 \%$ of all $\mathrm{Cr}(\mathrm{VI})$ species existing in aqueous solutions $\left(\mathrm{H}_{2} \mathrm{CrO}_{4}, \mathrm{CrO}_{4}{ }^{2-}, \mathrm{Cr}_{2} \mathrm{O}_{7}{ }^{2-}\right.$, $\mathrm{HCr}_{2} \mathrm{O}_{7}^{2-}$, and $\mathrm{HCrO}_{4}^{-}$) at an optimal $\mathrm{pH}=3$ [22-24]. Under the high acidic conditions $\mathrm{K}_{2} \mathrm{Cr}_{2} \mathrm{O}_{7}$ was transformed into the $\mathrm{H}_{2} \mathrm{Cr}_{2} \mathrm{O}_{7}$ form, and after the ionization $\mathrm{HCr}_{2} \mathrm{O}_{7}^{-}$and/or $\mathrm{Cr}_{2} \mathrm{O}_{7}^{2-}$ forms existed in aqueous solution as represented by the following equation (2):

$$
\mathrm{HCr}_{2} \mathrm{O}_{7}^{-} \rightleftharpoons \mathrm{Cr}_{2} \mathrm{O}_{7}^{2-}+\mathrm{H}^{+}
$$

In this equation and under acidic conditions the equilibrium moves toward the left in the direction of extracting $\mathrm{HCr}_{2} \mathrm{O}_{7}^{-}$[25-26]. The behavior of the adsorption of $\mathrm{HCr}_{2} \mathrm{O}_{7}^{-}$ions on PVC-0.75CX[4] polymer in acidic medium was explained by the possible protonation of nitrogen atoms in triazole ring [27]. However, acidic conditions at low $\mathrm{pH}$ values may be contributed to the neutraliza-

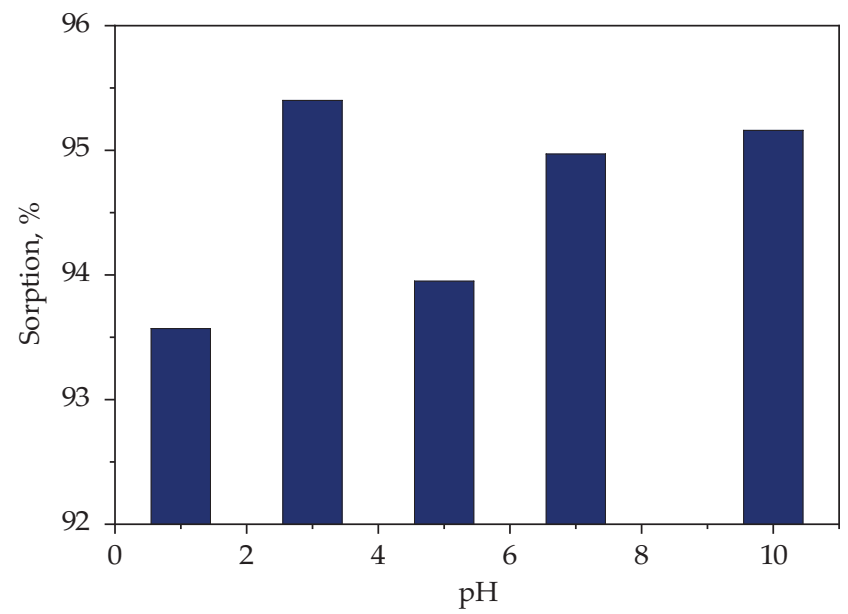

Fig. 7. Effect of $\mathrm{pH}$ on the sorption of $\mathrm{Cr}(\mathrm{VI})$ onto PVC-0.75CX[4] at $25^{\circ} \mathrm{C}$ for 1 hour 


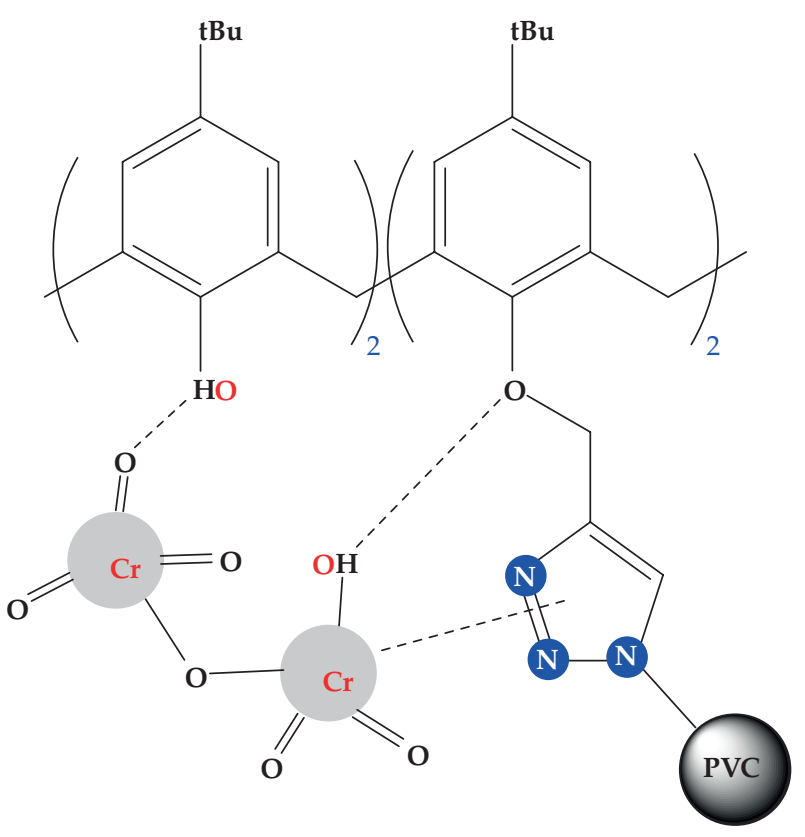

Fig. 8. Suggested $\mathrm{Cr}(\mathrm{VI})$ sorption mechanism

tion of the negative charge of adsorbent surface, which means more adsorption of the hydrogen dichromate ions by solid intermolecular attraction forces linking the chromate ion and oxygen functionalities onto the backbone of adsorbent polymer [28].

\section{CONCLUSIONS}

In this study, calixarene-based covalent polymers as a new generation of materials with very interesting features were described. The synthesis of a novel polymeric material PVC-0.75CX[4] via click chemistry, by coupling the calixarene terminal alkyne with azide PVC, was presented. The experiments on the removal of $\mathrm{Cr}(\mathrm{VI})$ species from aqueous solutions revealed a high sorption percentage of $95.5 \%$ at $\mathrm{pH}=3$ which could be attributed to the adsorbent large surface area. Thermal behavior of the prepared material showed high stability which could be reached at $350^{\circ} \mathrm{C}$. Thus, these thermal properties reflected a positive character of this polymer as an adsorbent of metal ions in various industrial processes where high temperature of water purification may be needed.

\section{ACKNOWLEDGMENT}

The authors would like to thank the Tunisian Ministry (Research Unit: 05/UR/12-05) for financing this project.

\section{REFERENCES}

[1] Gutsche C.D., Alam I., Iqbal M. et al.: Journal of Inclusion Phenomena and Molecular Recognition Chemistry 1989, $7,61$. https://doi.org/10.1007/BF01112783

[2] Alpaydin S., Yilmaz M., Ersoz M.: Separation Science and Technology 2005, 39, 2189. https://doi.org/10.1081/SS-120039310
[3] Minhas F.T., Solangi I.B., Memon S. et al.: Separation Science and Technology 2010, 45, 1448. https://doi.org/10.1080/01496391003652791

[4] He Z., Ye G., Jiang W.: Chemistry - A European Journal 2014, 21, 3005. https://doi.org/10.1002/chem.201405912

[5] Wankasi D., Dikio E.D.: Journal of Chemistry 2014, 2014, ID 817527. https://doi.org/10.1155/2014/817527

[6] Ouerghui A., Elamari H., Dardouri M. et al.: Reactive and Functional Polymers 2016, 100, 191. https://doi.org/10.1016/j.reactfunctpolym.2016.01.016

[7] Guo D.-S., Liu Y.: Chemical Society Reviews 2012, 41, 5907. https://doi.org/10.1039/C2CS35075K

[8] Kang Y., Rudkevich D.M.: Tetrahedron 2004, 60, 11219. https://doi.org/10.1016/j.tet.2004.08.063

[9] Gokoglan T.C., Soylemez S., Kesik M. et al.: RSC Advances 2015, 5, 35940. https://doi.org/10.1039/C5RA03933A

[10] Zhang Y., Su K., Hong Z. et al.: Industrial \& Engineering Chemistry Research 2020, 59, 7247. https://doi.org/10.1021/acs.iecr.9b05312

[11] Chen M., Shang T., Fang W. et al.: Journal of Hazardous Materials 2011, 185, 914. https://doi.org/10.1016/j.jhazmat.2010.09.107

[12] Kitano H., Hirabayashi T., Ide M. et al.: Macromolecular Chemistry and Physics 2003, 204, 1419. https://doi.org/10.1002/macp.200350008

[13] Trivedi U.V., Menon S.K., Agrawal Y.K.: Reactive and Functional Polymers 2002, 50, 205. https://doi.org/10.1016/S1381-5148(01)00106-7

[14] Tabakci M., Yilmaz M.: Bioresource Technology 2008, 99, 6642. https://doi.org/10.1016/j.biortech.2007.11.066

[15] Prabawati S.Y., Jumina, Santosa S.J. et al.: International Journal of Advances in Chemical Engineering and Biological Sciences 2014, 1, 25. https://doi.org/10.15242/IJACEBS.C1113038

[16] Khan S., Qureshi I., Shifa M.S. et al.: International Journal of Environmental Analytical Chemistry 2019, 99, 1123. https://doi.org/10.1080/03067319.2019.1625346

[17] Gutsche C.D., Iqbal M.: Organic Syntheses, Coll. 1993, 8, 75; 1990, 68, 234. https://doi.org/10.15227/orgsyn.068.0234

[18] Asfari Z., Bilyk A., Bond C. et al.: Organic \& Biomolecular Chemistry 2004, 2, 387. https://doi.org/10.1039/B308214H

[19] Becker G.W.: Kolloid-Zeitschrift 1955, 140, 1. https://doi.org/10.1007/BF01513351

[20] Jia P.-Y., Bo C.-Y., Zhang L.-Q. et al.: Journal of Industrial and Engineering Chemistry 2015, 28, 217. https://doi.org/10.1016/j.jiec.2015.02.017

[21] Sayin S., Yilmaz M.: Journal of Chemical \& Engineering Data 2011, 56, 2020. https://doi.org/10.1021/je1010328 
[22] Kotaś J., Stasicka Z.: Environmental Pollution 2000, 107, 263. https://doi.org/10.1016/S0269-7491(99)00168-2

[23] Han X., Wong Y.S., Wong M.H. et al.: Journal of Hazardous Materials 2007, 146, 65. https://doi.org/10.1016/j.jhazmat.2006.11.053

[24] Yu X.-Z., Zhang X.-H.: Ecotoxicology 2014, 23, 734. https://doi.org/10.1007/s10646-014-1187-9

[25] Qureshi I., Memon S., Yilmaz M.: Journal of Hazardous Materials 2009, 164, 675.

https://doi.org/10.1016/j.jhazmat.2008.08.076
[26] Beverskog B., Puigdomenech I.: Corrosion Science 1997, 39, 43. https://doi.org/10.1016/S0010-938X(97)89244-X

[27] Abboud J-L.M., Foces-Foces C., Notario R. et al.: European Journal of Organic Chemistry 2001, 2001, 3013. h t t p s : / / d o i.org / $10.1002 / 1099$ -0690(200108)2001:16<3013::AID-EJOC3013>3.0.CO;2$-\mathrm{Y}$

[28] Rao M., Parwate A.V., Bhole A.G.: Waste Management 2002, 22, 821.

https://doi.org/10.1016/S0956-053X(02)00011-9

Received 25 XI 2021.

\section{2-14 July 2022 Krakow, Poland}

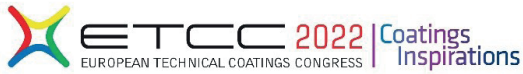

Since 1950

www.etcc2022.org

\section{Kongres ETCC2022 NOWY TERMIN 12-14 lipca 2022}

Z powodu światowych restrykcji związanych z pandemią SARS CoV-2, nowy termin kongresu ETCC2022 - European Technical Coatings Congress (poprzednio ETCC2020) ustalony na 12-14 lipca 2022 w Krakowie

Prezentacje ETCC2022 dotyczą najnowszych osiągnięć nauki i techniki w zakresie:

farb, lakierów, surowców, klejów, materiałów budowlanych, technologii i koncepcji z nimi związanych.

\section{Nowy, dodatkowy TERMIN ZGŁASZANIA ABSTRAKTÓW: 30 STYCZNIA 2022}

\section{Najważniejsze Fakty dotyczące Kongresu:}

(0) Program ETCC2022 zawiera 138 referatów oraz 68 prezentacji posterowych przedstawianych przez 200 autorów z wielu krajów całego świata. Szczegóły w programie kongresu: www.etcc2022.org/en/congress/congress-program

๑) Możliwość publikowania wystąpień kongresowych w renomowanych czasopismach, szczegóły: www.etcc2022.org/en/congress/publication-in-journals

( ) Przygotowano wystawę towarzyszącą kongresowi, szczegóły dostępne na www.etcc2022.org/en/congress/registration-form-for-exhibitors

( ) Ustalono program sesji "Summer School" dedykowanej młodym naukowcom. www.etcc2022.org/en/congress/summer-school

ETCC2022. Innowacje i Wymierne Korzyści:

W ciągu trzech dni kongresu odbędą się prezentacje plenarne, 6 sesji równoległych, prezentacje posterów oraz wystawa.

Prelegenci reprezentują największe firmy, instytuty i uniwersytety całego świata

Wszystkie dotychczasowe warunki i ustalenia, w tym:

(อ) Rejestracja do udziału w kongresie

() Dokonane opłaty kongresowe

๑) Przesłane wystąipienia: referaty oraz postery

(0) Rejestracje do udziału w wystawie

() Zgłoszenia do sesji „Summer School" dla młodych naukowców

Pozostają ważne w nowym terminie kongresu.

\section{Organizatorzy kongresu ETCC2022:}

Europejska Federacja FATIPEC - Federation of Associations of Technicians for Industry of Paints in European Countries (www.fatipec.com), oraz

Stowarzyszenie Inżynierów i Techników Przemysłu Chemicznego SITPChem (www.sitpchem.org.pl)

W przypadku pytań prosimy o kontakt, e-mail: etcc2022@sitpchem.org.pl 